\title{
THE ASSESSMENT OF THE SLIP INFLUENCE ON THE DEFLECTION OF THE STEEL PLATE-CONCRETE COMPOSITE BEAMS
}

\author{
D. KISALA ${ }^{1}$, K. FURTAK ${ }^{2}$
}

\begin{abstract}
The aim of this paper is to present an assessment of the slip influence on the deflection of the steel plate-concrete composite beams, which are a new type of a design concept. The proposed method is based on the procedure included in the PN-EN 1992-1-1, which has been modified with taking into consideration interface slip. The theoretical analysis was verified by experimental studies.
\end{abstract}

Keywords: composite beam, deflection, interface slip, steel-plate concrete composite structures.

\section{INTRODUCTION}

The past decade has witnessed a rapid development of composite structures, which are successfully used in civil engineering. Their continuous evolution is a result of rational use of basic properties of concrete and steel. The efforts to improve well known solutions have led to a new design concept, i.e. steel plate-concrete composite beams (SPCC). The concept is based on traditional composite structures, but also is inspired by the methods of strengthening reinforced concrete beams with a glued steel plate. The idea of a new design solution involves replacing the steel part of the traditional composite structure, which was constructed generally in the form of a beam or plate girder, by a steel plate connected to concrete by shear connectors. In contrast to the conventional reinforced concrete beams, rebars are replaced with the steel plate.

\footnotetext{
${ }^{1}$ MSc., Eng., Cracow University of Technology, Faculty of Civil Engineering, ul. Warszawska 24, 31-155 Cracow, Poland, e-mail: dkisala@pk.edu.pl

${ }^{1}$ Prof. Ph.D. Eng., Cracow University of Technology, Faculty of Civil Engineering, ul. Warszawska 24, 31-155 Cracow, Poland, e-mail: kfurtak@pk.edu.pl
} 


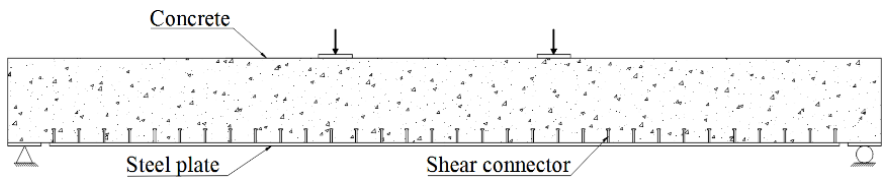

Fig. 1. Construction scheme of a steel plate-concrete composite beam

In this paper a method of calculating the deflection of steel-concrete composite beams is proposed. It is based on the procedure included in PN-EN 1992-1-1, which has been modified by taking into consideration the deformability of the connection between steel and concrete. The given solution was verified by results of experimental studies [1].

\section{Problem}

Experimental studies of the steel-plate concrete beams have shown that with the application of the procedures proposed in the standard codes it is not possible to correctly calculate the deflection of the structure [1].

Table. 1. Experimental and theoretical deflection results [1]

\begin{tabular}{|c|c|c|c|c|c|}
\hline & \multicolumn{5}{|c|}{ Deflection [mm] } \\
\hline Beam No. & SCCB-2 & SCCB-3 & SCCB-5 & SCCB-7 & SCCB-8 \\
\hline Experimental results & 9.42 & 8.66 & 8.97 & 7.85 & 8.53 \\
\hline ACI & 7.24 & 6.68 & 6.50 & 7.06 & 6.55 \\
\hline EC 2 & 7.12 & 6.57 & 6.35 & 6.96 & 6.45 \\
\hline Chinese Code & 8.33 & 7.81 & 7.58 & 8.30 & 7.61 \\
\hline
\end{tabular}

This is a result of the hybrid nature of the response of this type of elements which combine the features typical of reinforced concrete and those of composite structures. The underestimation of the deflection is caused mostly by disregarding studs deformability, which results in neglecting of the influence of the slip on the stiffness of the beam and consequently also the deflection. In addition, an important issue which affects the value of the deflection is cracking of the reinforced concrete beam [2]. It differs from cracking in traditional reinforced concrete beams due to dissimilar interaction between rebars and steel plate with concrete. The use of the standard cracking theory for reinforced concrete elements is possible, but it is flawed. 


\section{THEORETICAL ANALYSIS}

\subsection{DEFLECTION OF THE REINFORCED CONCRETE STRUCTURE}

According to [3], the structure fulfils the requirements of serviceability limit state due to deflection, when it does not exceed the limit:

$$
f \leq f_{\lim }
$$

where:

$f$ - deflection of the beam, $f_{\text {lim }}$ - beam deflection limit.

In addition, the deflection of reinforced concrete structures can be divided into two phases: before and after cracking. The deflection could be calculated using the formula [4]:

$$
f=\alpha_{k} \frac{M L^{2}}{B}
$$

where:

$\alpha_{k}$ - coefficient which depends on the load and static diagram - for simply supported beam with loading case of four-point bending it is $\frac{1}{8}-\frac{\lambda^{2}}{6}, M$ - bending moment, $L$ - length, $E_{c}-$ modulus of elasticity of concrete, $I_{I}$ - second moment of area of the un-cracked section, $I_{I I}-$ second moment of area of the cracked section, $B$ - flexural stiffness of the element: $B_{I}=E_{c} I_{I}-$ in the first phase before cracking, $B_{I I}=E_{c} I_{I I}-$ in the second phase after cracking.

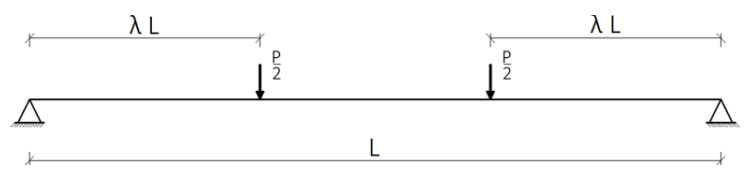

Fig. 2. Static diagram and the load arrangement of the beam 
Since it is difficult to determine and take into account the variable stiffness of the element in length, the average stiffness can be used as a simplification. Then the distribution coefficient allowing for tensioning stiffening is given by expression [4]:

$$
\zeta=1-\beta_{1} \beta_{2}\left(\frac{\sigma_{s r}^{I I}}{\sigma_{s}^{I I}}\right)^{2}=1-\beta_{1} \beta_{2}\left(\frac{M_{c r}}{M}\right)^{2}=1-\left(\frac{M_{c r}}{M}\right)^{2}
$$

where:

$\beta_{1}=1.0$ - coefficient taking account the bond properties of the bar (value for a rebar), $\beta_{2}=1.0-$ coefficient taking account the influence of the duration of the loading or of repeated loading on the average strain (value for a single short-term loading), $\sigma_{s r}^{I I}$ - stress in tension reinforcement calculated on the basis of a cracked section under the loading conditions causing the first crack, $\sigma_{s}^{I I}-$ stress in tension reinforcement calculated on the basis of a cracked section, $M_{c r}$ - cracking moment.

If the steel plate is assumed to act as the longitudinal reinforcement and the influence of concrete shrinkage is omitted, the deflection can be calculated as [4]:

$$
f_{r}=(1-\zeta) f_{I}+\zeta f_{I I}
$$

where:

$f_{I}=\alpha_{k} \frac{M L^{2}}{B_{I}}-$ deflection of un-cracked conditions, $f_{I I}=\alpha_{k} \frac{M L^{2}}{B_{I I}}-$ deflection of fully cracked conditions.

The calculated deflection of the steel plate-concrete composite structure will be much smaller than the values obtained in experimental studies, mainly due to the slip between the steel plate and the concrete.

\subsection{ASSUMPTIONS FOR THE CALCULATION OF THE THEORETICAL DEFLECTION \\ TAKING INTO ACCOUNT THE SLIP}


In serviceability limit state we presume the linear elastic behaviour of the structure. In addition, it is necessary to assume that [5]:

- interface shear force is proportional to slip,

- shear stiffness at the interface is uniform and constant over the length of the beam,

- steel plate and reinforced concrete beam in the same cross-section have the same curvature and rotation,

- the concrete in tension is ignored after the first crack occurred,

- steel and concrete are modelled using a linear elastic analysis.

These are the classic assumptions adopted in reinforced concrete and composite structures. Based on them, we can obtain the relationship between interface forces, slip and the properties of studs can be obtained [6]:

$$
p \tau=k s
$$

where:

$p$ - pitch between the studs, $\tau$ - horizontal shear along the interface per unit length, $k$ - shear-slip stiffness of the stud, $s$-slip.

The formula to calculate shear stiffness of connectors can be adopted according to [5] as:

$$
k=0.66 N_{s} P_{\max }
$$

where:

$N_{s}$ - number of studs per row, $P_{\max }-$ design shear resistance of stud according to [7].

\subsection{ADDITIONAL DEFLECTION DUE TO SLIP}

Based on the derivation formula for slip for a simply supported beam loaded along the entire length $[6,8]$, an analogous relationship can be deduced for a four-point load case. 


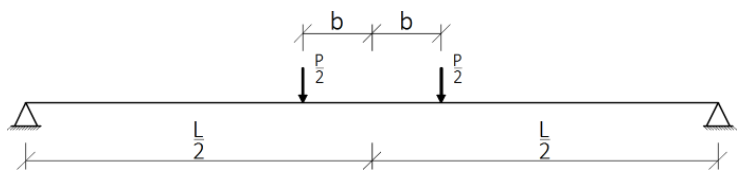

Fig. 3. Static diagram of analysed steel plate-concrete composite beam

Analysing the equilibrium equations and assuming that $x=0$ is in the middle of the beam:

$$
\begin{gathered}
\frac{d F}{d x}=-\tau \\
\frac{d M_{c}}{d x}+V_{c}=\frac{1}{2} h_{c} \tau \\
\frac{d M_{s}}{d x}+V_{s}=\frac{1}{2} h_{s} \tau \\
V_{c}+V_{s}=\frac{P}{2}
\end{gathered}
$$

where:

$F$ - longitudinal force, $M_{c}$ - bending moment on concrete section, $M_{s}$ - bending moment on steel section, $V_{c}$ - vertical shear in concrete, $V_{s}$ - vertical shear in steel, $P$ - applied load, $r$ - vertical force per unit length at the interface, $h_{c}$-depth of the concrete beam, $h_{s}$-depth of the steel plate.

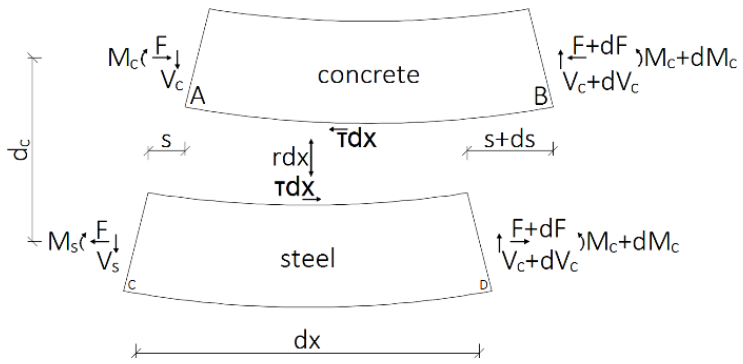

Fig. 4. Infinitesimal element of analysed steel plate-concrete composite beam [8]

Assuming further:

$$
d_{c}=\frac{1}{2}\left(h_{c}+h_{s}\right)
$$


and using the relations (3.8), (3.9) and (3.10):

$$
\frac{d M_{c}}{d x}+\frac{d M_{s}}{d x}+\frac{P}{2}=d_{c} \tau
$$

is obtained.

When calculating the composite structure with sufficient uplift resistance, the following equation can be obtained:

$$
\phi=\frac{M_{s}}{E_{s} I_{s}}=\frac{n M_{c}}{E_{s} I_{c}}
$$

where:

$\phi$ - curvature, $E_{s}$ - elasticity modulus of steel, $n=\frac{E_{c}}{E_{s}}-$ modular ratio, $I_{c}-$ moment inertia of concrete section, $I_{s}-$ moment inertia of steel section.

The longitudinal strains in concrete and in steel are [8]:

$$
\begin{gathered}
\varepsilon_{A B}=\frac{1}{2} h_{c} \phi-\frac{n F}{E_{s} A_{c}} \\
\varepsilon_{C D}=-\frac{1}{2} h_{s} \phi-\frac{F}{E_{s} A_{s}}
\end{gathered}
$$

where:

$A_{c}$ - area of concrete, $A_{s}$ - area of steel.

The difference between $\varepsilon_{A B}$ and $\varepsilon_{C D}$ is the slip strain $\varepsilon_{s}$. Therefore:

$$
\varepsilon_{s}=\varepsilon_{A B}-\varepsilon_{C D}=\frac{d s}{d x}=\phi d_{c}-\frac{F}{E_{s}}\left(\frac{n}{A_{c}}+\frac{1}{A_{s}}\right)
$$

Using formulas (3.12) and (3.13): 


$$
\frac{d \phi}{d x} E_{s}\left(I_{s}+\frac{I_{c}}{n}\right)+\frac{P}{2}=d_{c} \tau
$$

Introducing:

$$
I_{0}=\left\{\begin{array}{l}
\frac{I_{c I}}{n}+I_{s}, P \leq P_{c r} \\
\frac{I_{c I I}}{n}+I_{s}, P_{c r}<P
\end{array}\right.
$$

where:

$I_{c I}$ - moment inertia of concrete un-cracked section, $I_{c I I}$ - moment inertia of concrete cracked section corresponding to applied load.

Using (3.5) we can write:

$$
\frac{d \phi}{d x}=\frac{\frac{k s d_{c}}{p}-\frac{P}{2}}{E_{s} I_{0}}
$$

Differentiating (3.16) we can obtain:

$$
\frac{d^{2} s}{d x^{2}}=\frac{d \phi}{d x} d_{c}-\frac{d F}{d x} \cdot \frac{1}{E_{s}}\left(\frac{n}{A_{c}}+\frac{1}{A_{s}}\right)
$$

and introducing:

$$
A_{0}=\frac{A_{s} A_{c}}{n A_{s}+A_{c}}
$$

gives:

$$
\frac{d^{2} s}{d x^{2}}=\frac{k s}{p E_{s} I_{0}}\left(d_{c}^{2}+\frac{I_{0}}{A_{0}}\right)-\frac{\frac{P}{2} d_{c}}{E_{s} I_{0}}
$$


Introducing:

$$
\begin{gathered}
\frac{1}{A^{\prime}}=\left(d_{c}^{2}+\frac{I_{0}}{A_{0}}\right) \\
\alpha^{2}=\frac{k}{p E_{s} I_{0} A^{\prime}} \\
\beta=\frac{A^{\prime} p d_{c}}{k}
\end{gathered}
$$

gives results in a standard form:

$$
\frac{d^{2} s}{d x^{2}}-\alpha^{2} s+\alpha^{2} \beta \frac{P}{2}=0
$$

Solving for s:

$$
s(x)=C_{1} e^{\alpha x}+C_{2} e^{-\alpha x}+\frac{\beta P}{2}
$$

where:

$C_{1}, C_{2}$ - constants of integration.

Using the boundary conditions $s(0)=0$ and $\frac{d s}{d x}\left(\frac{L}{2}\right)=0, C_{1}$ and $C_{2}$ can be found and it gives slip s in terms of $\mathrm{x}$ :

$$
s(x)=\frac{\beta P\left(1+e^{\alpha L}-e^{\alpha x-\alpha L}+e^{-\alpha x}\right)}{2\left(1+e^{-\alpha L}\right)}
$$

After differentiation the formula for the strains resulting from slip is obtained:

$$
\varepsilon_{s}=\frac{d s}{d x}(x)=\frac{\alpha \beta P\left(e^{-\alpha x}-e^{\alpha x-\alpha L}\right)}{2\left(1+e^{-\alpha L}\right)}
$$




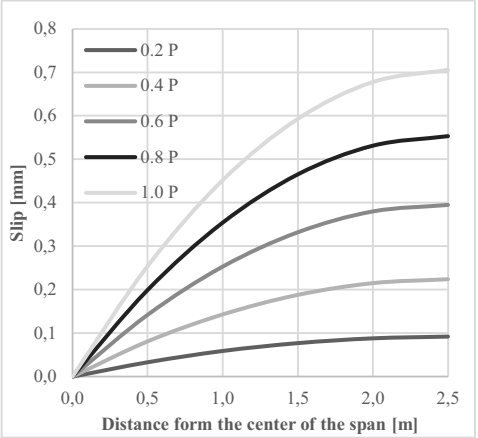

Fig. 5. Slip distribution along the SCCB-8 beam Fig. 6. Slip strain distribution along the SCCB-8 at different levels of load $(\mathrm{P}=162,5 \mathrm{kN})$

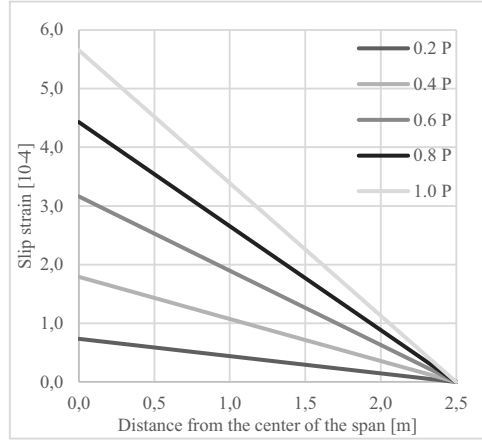

beam at different levels of load $(\mathrm{P}=162,5 \mathrm{kN})$

Additional curvature of the beam as a result of the slip is:

$$
\Delta \phi=\frac{\varepsilon_{s}}{h}
$$

where:

$h$ - depth of entire section.

Using $\frac{\Delta f(x)}{d x}(0)=0$ and $\Delta f(x)\left(\frac{L}{2}\right)=0$, the value of the additional deflection due to slip at the interface at the distance $b$ from the centre of the span of element can be calculated as:

$$
\Delta f=\Delta f(b)=\beta P\left(\frac{L-2 b}{4 h}+\frac{e^{\alpha b}-e^{\alpha L-\alpha b}}{2 \alpha h\left(1+e^{\alpha L}\right)}\right)
$$

Using the relations derived for the reinforced concrete element (3.4) and taking into account the additional deflection due to the behaviour similar to that of the composite structure (3.31), the total deflection of the steel plate-concrete composite structure can be expressed as:

$$
f_{\text {tot }}=f_{r}+\Delta f
$$




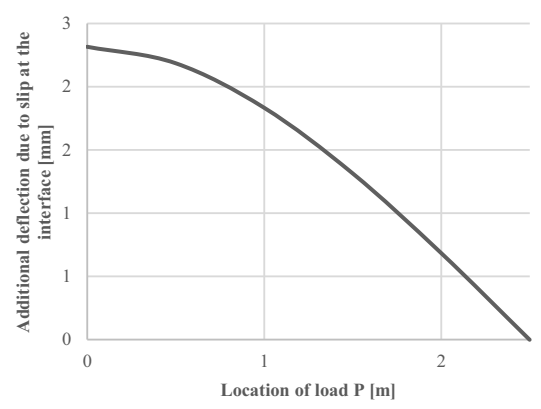

Fig. 7. Additional deflection of the beam depending on the location of load $\mathrm{P}=162.5 \mathrm{kN}$ for beam SCCB-8

\subsection{THE RESULTS OF THE THEORETICAL ANALYSIS}

The basic properties of the tested beams are shown in Table 2, and the results of theoretical analysis in Figure 9 and 10. Figure 8 shows the geometry of SCCB- 8 beam. Other beams are identical except for the parameters indicated in Table 2 .

Table 2. Characteristics of the main parameters of the tested beams [1]

\begin{tabular}{|c|c|c|c|c|c|}
\hline Parameter & SCCB-2 & SCCB-3 & SCCB-5 & SCCB-7 & SCCB-8 \\
\hline Depth of concrete beam [mm] & \multicolumn{5}{|c|}{500} \\
\hline Width [mm] & \multicolumn{5}{|c|}{5000} \\
\hline Span [mm] & \multicolumn{5}{|c|}{50} \\
\hline $\begin{array}{c}\text { Depth of steel plate [mm] } \\
\text { Length of steel plate [mm] }\end{array}$ & 5200 & 5200 & 4700 & 4700 & 4700 \\
\hline $\begin{array}{c}\text { Length of shear span [mm] } \\
\text { Space between studs [mm] }\end{array}$ & 1500 & 1500 & 2500 & 2500 & 2000 \\
\hline $\begin{array}{c}\text { Characteristic value of compressive strength } \\
\text { of concrete [MPa] }\end{array}$ & 40.7 & 46.3 & 45.1 & 46.4 & 37.4 \\
\hline $\begin{array}{c}\text { Characteristic value of yield strength of } \\
\text { steel plate [MPa] }\end{array}$ & 327.0 & 291.0 & 327.0 & 327.0 & 327.0 \\
\hline \begin{tabular}{c} 
Tensile strength of steel plate [MPa] \\
\hline
\end{tabular} & 477.0 & 446.0 & 477.0 & 477.0 & 477.0 \\
\hline
\end{tabular}



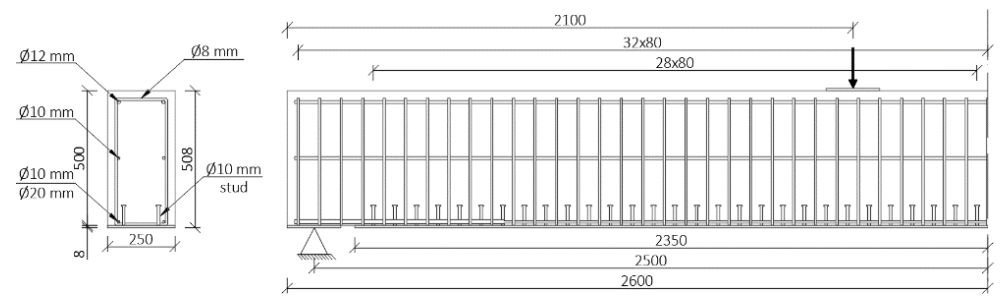

Fig. 8. The geometry of steel plate-concrete composite beams (SCCB-8)

The deflections calculated at service load are much smaller than the deflection at the ultimate flexural strength calculated by means of simplified plastic method. The study [1] assumes that half of the ultimate load of the beam was the value for which the deflection was computed. This assumption is based on the fact that in the actual design deflection is calculated for real load levels which never reach the values close to a load carrying capacity and mostly are of about 50 to $60 \%$. Therefore, theoretical analysis using the proposed approach shows that this assumption is justified, since it corresponds well with the actual conditions in which the beam is used. The plot in Figure 9 confirms that the analysis using the proposed theory is correct for this or slightly higher level of loads. Therefore, further calculations were carried out using this assumption.

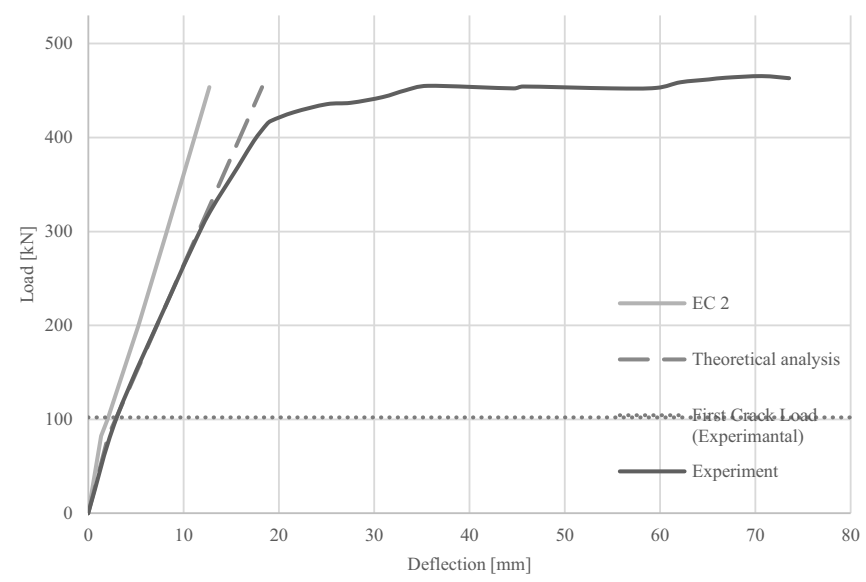

Fig. 9. Load-deflection curve for SCCB-5 beam 
a)

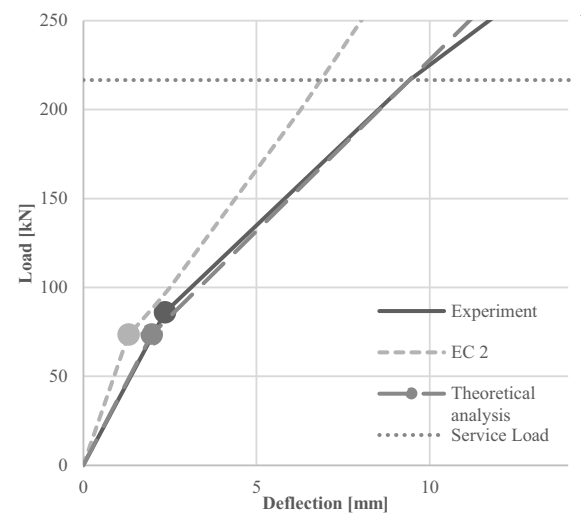

c)

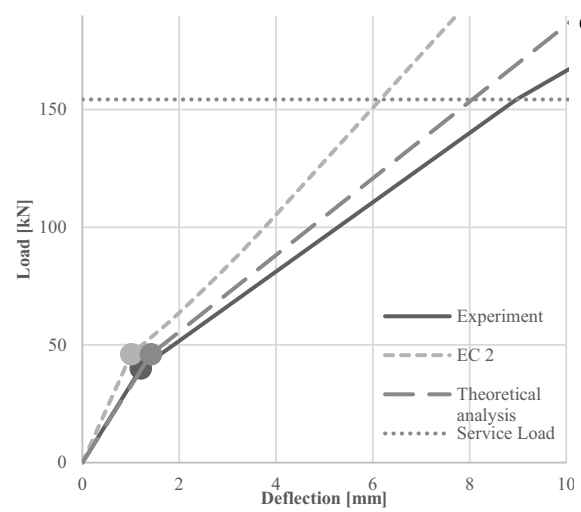

b)

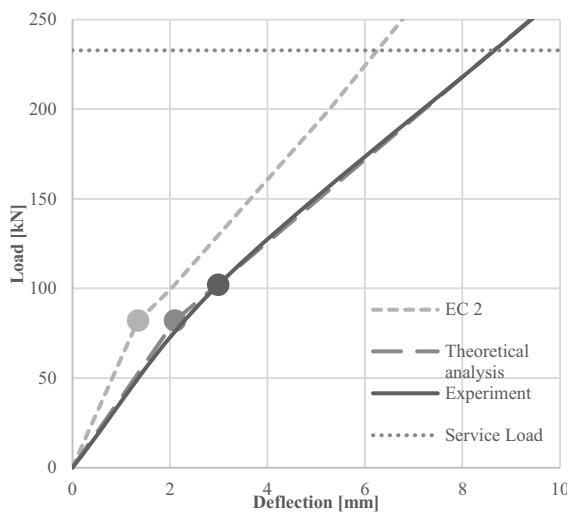

d)

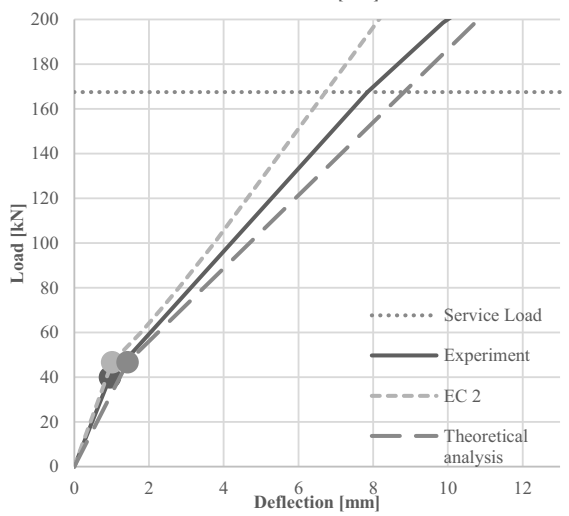

e)

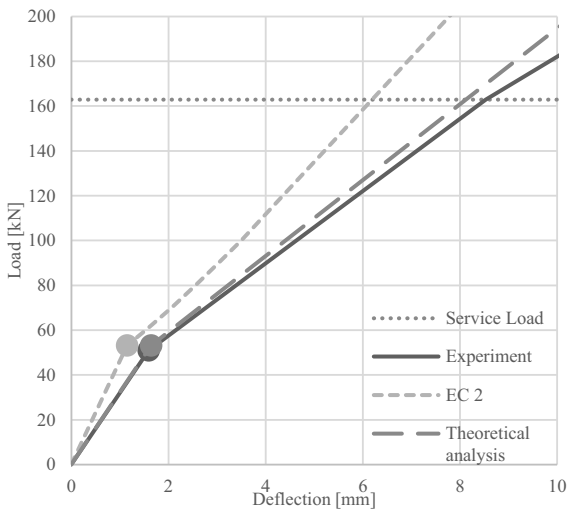

Fig. 10. Comparison of load-deflection curves for tested beams at the half of the ultimate load of tested beams: a) SCCB-2, b) SCCB-3, c) SCCB-5, d) SCCB-7, e) SCCB 8 (the name of the beams in accordance with [1], dot indicates the first crack load) 
The analysis of load-deflection curves shows the characteristic behaviour of the element. Once cracking occurs, stresses in the steel part of the composite beam increase significantly, which can be observed on the graph as a sudden change in the slope of the curve. In the nonlinear region subsequent cracking occurs. It causes a further increase in the stress level of the steel, which however is reduced to some extent by the stiffening effect resulting from the cooperation of concrete and steel sections between the cracks.

Comparison of the curves for the five tested beams shows a good correlation of results, particularly in the second phase after cracking of the reinforced beam, which can be seen in plots in Figure 10.

\section{SUMMARY AND CONCLUSIONS}

The method of calculating deflection of the steel plate-concrete composite beam presented in this paper can be successfully used in practical applications. The use of the approach specified in the code [3], taking into account the additional deflection due to the slip at the interface (resulting from deformability of shear connectors), can properly estimate the response of the discussed elements. The analysis of the deflection cannot be used above the service load (approximately half of the ultimate load) because convergence of results is not satisfactory. This is due to the deterioration of the interface between the steel plate and the concrete as a result of excessive cracking and the nonlinear force-slip relations for shear connectors. 


\section{REFERENCES}

1. Nie J., Zhao J.: Flexural Behaviour of Steel-Concrete Composite Beams, Key Engineering Materials, Vols. 400402, 2009, pp. 37-42.

2. Furtak K.: Mosty zespolone, Wydawnictwo Naukowe PWN, Warszawa-Kraków, 1999.

3. EN 1992-1-1:2004 Design of concrete structures. General rules and rules for buildings.

4. Łapko A., Jensen B. C.: Podstawy projektowania i algorytmy obliczeń konstrukcji żelbetowych, Arkady, Warszawa, 2006.

5. Nie J., Fan J., Cai C. S.: Stiffness and Deflection of Steel-Concrete Composite Beams under Negative Bending, Journal of Structural Engineering, 11/2004.

6. Nie J., Cai C. S.: Steel-Concrete Composite Beams Considering Shear Slip Effects, Journal of Structural Engineering, Vol. 129, No. 4, April 2003, pp. 495-506.

7. EN 1994-1-1:2008 Design of composite steel and concrete structures. General rules and rules for buildings.

8. Johnson R. P.: Composite Structures of Steel and Concrete. Volume 1. Beams, Columns, Frames and Applications in Building, Crosby Lockwood Staples, 1975.

9. Nawy E. G.: Prestressed concrete: A fundamental Approach, 5th Edition, Prentice Hall, 2009.

10. Ansys 10.0 Release Documentation for Ansys.

11. Amer M. I., Saad k. M., Qusay W.A.: Finite element modeling of composite steel-concrete beams with external prestressing, International Journal of Civil and Structural Enginnering, Vol. 3, No. 1, 2012.

\section{LIST OF FIGURES AND TABLES:}

Fig. 1. Construction scheme of a steel plate-concrete composite beam

Rys. 1. Schemat belki zespolonej typu stalowa blacha-beton

Fig. 2. Static diagram and the load arrangement of the beam

Rys. 2. Schemat statyczny i układ obciążenia belki

Fig. 3. Static diagram of analysed steel plate-concrete composite beam

Rys. 3. Schemat statyczny analizowanej belki zespolonej typu stalowa blacha-beton

Fig. 4. Infinitesimal element of analysed steel plate-concrete composite beam [7]

Rys. 4. Wycinek analizowanej belki zespolonej typu stalowa blacha-beton

Fig. 5. Slip distribution along the SCCB-8 beam at different levels of load $(\mathrm{P}=162,5 \mathrm{kN})$

Rys. 5. Rozkład poślizgu na długości belki SCCB-8 w zależności od przyłożonego obciążenia $(\mathrm{P}=$ $162,5 \mathrm{kN})$

Fig. 6. Slip strain distribution along the SCCB- 8 beam at different levels of load $(\mathrm{P}=162,5 \mathrm{kN})$

Rys. 6. Rozkład odkształceń wynikających z poślizgu na długości belki SCCB-8 w zależności od przyłożonego obciążenia $(\mathrm{P}=162,5 \mathrm{kN})$

Fig. 7. Additional deflection of the beam depending on the location of load $\mathrm{P}=162.5 \mathrm{kN}$ for beam

\section{SCCB-8}

Rys. 7. Dodatkowe ugięcie belki w zależności od położenia siły $\mathrm{P}=162.5 \mathrm{kN}$ dla belki SCCB-8 
Fig. 8. The geometry of steel plate-concrete composite beams (SCCB-8)

Rys. 8. Geometria belki zespolonej typu stalowa blacha-beton (SCCB-8)

Fig. 9. Load-deflection curve for SCCB-5 beam

Rys. 9. Zależność ugięcia od obciążenia dla belki SCCB-5

Fig. 10. Comparison of load-deflection curves for tested beams at the half of the ultimate load: a) SCCB-2, b) SCCB-3, c) SCCB-5, d) SCCB-7, e) SCCB 8 (the name of the beams in accordance with [1], dot indicates the first crack load)

Rys. 10. Porównanie zależności obciążenie-ugięcie dla badanych belek przy obciążeniu na poziomie połowy nośności belki: a) SCCB-2, b) SCCB-3, c) SCCB-5, d) SCCB-7, e) SCCB 8 (nazwa belki zgodnie z określeniami użytymi w [1], kropka wskazuje poziom obciążenia wywołującego pierwsze zarysowanie)

Tab. 1. Experimental and theoretical deflection results [1]

Tab. 1. Wyniki badań doświadczalnych i analiz teoretycznych [1]

Tab. 2. Characteristics of the main parameters of the tested beams [1]

Tab. 2. Charakterystyka głównych parametrów analizowanej belki [1] 


\section{OCENA WPLYWU POŚLIZGU NA UGIĘCIE BELEK ZESPOLONYCH TYPU STALOWA BLACHA-BETON}

Keywords: belka zespolona typu stalowa blacha-beton, konstrukcja zespolona, poślizg w płaszczyźnie zespolenia, ugięcia.

\section{SUMMARY:}

Konstrukcje zespolone od wielu lat z sukcesem są stosowane w budownictwie, a ich ciągły rozwój wynika z racjonalnego wykorzystania cech podstawowych materiałów stosowanych w budownictwie - betonu i stali. Ciągłe poszukiwania coraz to lepszych rozwiązań doprowadziły do powstania nowej koncepcji konstrukcyjnej - belek zespolonych typu stalowa blacha-beton. Wywodzi się ona z klasycznych konstrukcji zespolonych, ale czerpie również inspirację z metod wzmacniania żelbetowych belek za pomocą przyklejanych stalowych płaskowników. Pomysł nowego rozwiązania konstrukcyjnego zakłada zastąpienie części stalowej klasycznej konstrukcji zespolonej, która najczęściej była konstruowana w formie dwuteownika lub blachownicy, przez stalową blachę zespoloną z betonem za pomocą łączników (SPCC - steel plate-concrete composite). Przyczepność między tymi częściami składowymi belki zapewniają łączniki wiotkie w postaci sworzni.

Badania doświadczalne konstrukcji zespolonych typu stalowa blacha-beton wykazały, że zastosowanie procedur zaproponowanych w normach nie pozwala na poprawne obliczenie ugięć tego typu konstrukcji. Wynika to $\mathrm{z}$ hybrydowego charakteru pracy tego typu elementów, które łączą cechy typowych konstrukcji żelbetowych i zespolonych. Niedoszacowanie ugięć spowodowane jest w głównej mierze nieuwzględnieniem podatności łączników wiotkich, co powoduje pominięcie wpływu poślizgu w płaszczyźnie zespolenia na sztywność elementu, a w konsekwencji na ugięcia.

Istotnym zagadnieniem rzutującym na wartość ugięć jest zarysowanie belki żelbetowej. Jednak zarysowanie betonu w omawianych belkach różni się od tego występującego w klasycznych belek żelbetowych. Wynika to z innej współpracy prętów zbrojeniowych i blach stalowych z betonem. Wykorzystanie powszechnie znanych teorii zarysowania elementów żelbetowych jest możliwe, ale jest obarczone błędem.

W pracy zaproponowano sposób obliczania ugięć belek zespolonych typu stalowa blacha-beton. Bazuje on na procedurze ujętej w PN-EN 1992-1-1, która została zmodyfikowana w zakresie uwzględnienia podatności połączenia. W artykule przytoczono wzory do obliczania ugięć klasycznych konstrukcji żelbetowych z uwzględnieniem ich zarysowania. Ponadto wyprowadzono zależności na dodatkowe ugięcie wynikające z podatności łączników wiotkich, jako zależność nieliniową zależną od poziomu obciążenia oraz zarysowania konstrukcji. Wykorzystując zależności wyprowadzone dla konstrukcji żelbetowej oraz uwzględniając dodatkowe ugięcie wynikające z charakteru pracy zbliżonego do konstrukcji zespolonej podano propozycję obliczania całkowitego ugięcia konstrukcji zespolonej typu stalowa blacha-beton.

W ramach artykułu przeprowadzono i przedstawiono wyniki analiz teoretycznych z wykorzystaniem zaproponowanej procedury. Dodatkowo ze względu na to, że w przypadku stanu granicznego użytkowalności (SGU) dopuszcza się do pracy konstrukcje w zakresie sprężystym, konieczne jest przyjęcie następujących założeń: poślizg w płaszczyźnie zespolenia jest proporcjonalny do siły ścinającej, sztywność połączenia w płaszczyźnie zespolenia jest równomierna i ciągła na długości belki, stalowa blacha i żelbetowa belka w danym przekroju poprzecznym mają taką samą krzywiznę i obrót, beton w strefie rozciąganej po zarysowaniu jest pomijany, stal oraz beton są modelowane z zastosowaniem analizy liniowo-sprężystej. 
Podane rozwiązania zweryfikowano wynikami obcych badań doświadczalnych. Przyjęto założenie, że połowa obciążenia maksymalnego powodującego wyczerpanie nośności belki (z badania doświadczalnego), stanowiło wartość, dla której oblicza się maksymalne ugięcia. Założenie to wynika z faktu, że w przypadku rzeczywistych konstrukcji ugięcia oblicza się dla rzeczywistych poziomów obciążeń, które z zasady nigdy nie mają osiągnąć wartości zbliżonych do nośności belki, a najczęściej kształtują się na poziomie około $50 \div 60 \%$.

Analiza zaprezentowanych wykresów zależności pomiędzy obciążeniem, a ugięciami pokazuje charakterystyczną pracę elementu, która w pierwszej fazie zachowuje się liniowo-sprężyście. Trwa ona do momentu osiągnięcia obciążenia wywołującego powstanie pierwszej rysy, co skutkuje znacznym wzrostem naprężeń w części stalowej, a na wykresie objawia się załamaniem. W dalszej fazie pracy dochodzi do rozwoju zarysowania, a tym samym dalszego wzrostu naprężeń w stali, który jednak redukowany jest w pewnym stopniu przez efekt usztywnienia, wynikający ze współpracy betonu i stali na odcinkach pomiędzy rysami. Porównanie rezultatów badań i obliczeń teoretycznych dla pięciu belek pokazuje dobrą korelację wyników.

Zaprezentowany w niniejszej pracy sposób obliczania ugięć konstrukcji zespolonych typu stalowa płyta-beton może być $\mathrm{z}$ powodzeniem wykorzystany $\mathrm{w}$ zastosowaniach praktycznych. Wykorzystanie podejścia podanego $\mathrm{w}$ normie PN-EN 1992-1-1 z dodatkowym uwzględnieniem poślizgu w płaszczyźnie zespolenia wynikającego z podatności łączników wiotkich pozwala właściwie ocenić pracę omówionego typu elementów. Analiza ugięć na poziomie obciążeń użytkowych z wykorzystaniem zaprezentowanego podejścia nie może być stosowana $\mathrm{w}$ pełnym zakresie obciążenia elementu, ponieważ powyżej poziomu obciążeń użytkowych (około połowa obciążenia powodującego wyczerpanie nośności) zbieżność wyników przystaje być zadowalająca. Wynika to z zaburzenia strefy styku między stalową płytą i betonem wskutek nadmiernego zarysowania, a tym samym relacji siła-poślizg i podatności łączników. 